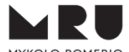

MYKOLO ROMERIO
UNIVERSITETAS
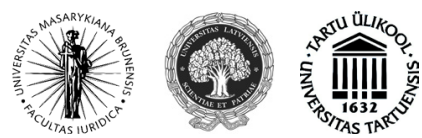

ISSN 1392-6195 (print) ISSN 2029-2058 (online) JURISPRUDENCIJA JURISPRUDENCE 2014, 21(2), p. 504-528

\title{
JŪRININKŲ DARBO IR SOCIALINĖS TEISĖS PAGAL MLC 2006
}

\author{
Oleg Drobitko \\ Mykolo Romerio universiteto Teisės fakulteto \\ Civilinès jurisprudencijos institutas \\ Ateities g. 20, LT-08303 Vilnius, Lietuva \\ Tel.: (+370 5) 2714525 \\ Elektroninis paštas: oleg.drobitko@inright.eu
}

Pateikta 2014 m. balandžio 14 d., parengta spausdinti 2014 m. gegužės 25 d.

doi:10.13165/JUR-14-21-2-09

\section{Ivadas}

1998 metais buvo priimta Tarptautinès darbo organizacijos (toliau - TDO) deklaracija dèl pagrindinių principų ir teisių darbe ${ }^{1}$. Šiame dokumente TDO aiškiai ir nedviprasmiškai deklaravo savo principinę nuostatą, kad socialinis teisingumas yra pagrindinis faktorius, kuris gali užtikrinti bendrą ir stiprią taiką, o ekonominė pažanga nèra vienintelis socialinę pažangą skatinantis veiksnys. Šioje deklaracijoje yra ịvardinti ir bendrieji teisès principai, kurių privalo laikytis visos valstybės, kurios yra TDO dalyvès socialinės apsaugos ir darbo srityje. Akivaizdu, kad mūsų valstybė, kaip

1 ILO Declaration on Fundamental Principles and Rights at Work and its Follow-up [interaktyvus]. International labour organization [žiūrèta 2014-04-27]. <http://www.ilo.org/declaration/ thedeclaration/textdeclaration/lang--en/index.htm >.

Jurisprudencija/Jurisprudence

(C) Mykolo Romerio universitetas, 2014

(C) Mykolas Romeris University, 2014
ISSN 1392-6195 (print), ISSN 2029-2058 (online) http://www.mruni.eu/lt/mokslo_darbai/jurisprudencija/ http://www.mruni.eu/en/mokslo_darbai/jurisprudencija/ 
Tarptautinès darbo organizacijos naré ${ }^{2}$, privalo užtikrinti tinkamą šių principų aiškinimą ir taikymą.

2013 m. birželio 13 d. ratifikuota 2006 m. Konvencija dèl darbo jūrų laivyboje ${ }^{3}$ (toliau - MLC 2006). Lietuvoje MLC 2006 įsigalios 2014 m. rugpjūčio 20 d. ${ }^{4}$ Šioje Konvencijoje TDO konstatuoja, kad šiuolaikinė tarptautinė laivyba yra globalaus pobūdžio ir tai lemia ypatingą jūrininkų socialinès apsaugos poreikị. Minètos Konvencijos nuostatos suderintos su 1998 m. Tarptautinès darbo organizacijos deklaracijoje itvirtintais principais, kurių privalo laikytis ir Lietuvos valstybe kaip Konvencijos dalyvè. Lietuvos saugios laivybos administracija per dvejus metus išdavė 2301 ir pratęsė 1329 jūrininko knygeles ${ }^{5}$. Tai leidžia tvirtinti, kad naujos Konvencijos įsigaliojimas palies nemažą dalị Lietuvos piliečių ir gyventojų teisių ir teisètų interesų. Atsižvelgiant ị tai kyla būtinybė išanalizuoti jau daromą Konvencijos ịtaką Lietuvos jūrininkų gyvenimui.

Rengiant MLC 2006 remtasi jau įsigaliojusiomis konvencijomis, kurios reglamentuoja jūrininkų darbą, ir visuotinai pripažintomis fundamentaliomis žmogaus teisėmis ir laisvėmis. Tarp kitų jūrininkų veiklą reglamentuojančių konvencijų galima nurodyti pagrindines: $1973 \mathrm{~m}$. Tarptautinė konvencija dèl teršimo iš laivų prevencijos, papildyta $1978 \mathrm{~m}$. protokolu (toliau - MARPOL 73/78)6 $; 1974 \mathrm{~m}$. Tarptautinè konvencija dèl žmogaus gyvybės apsaugos jūroje (toliau - SOLAS 74) ${ }^{7} ; 1978 \mathrm{~m}$. Tarptautinè konvencija dèl jūrininkų rengimo, atestavimo ir budejjimo normatyvų $\left(\right.$ toliau - STCW 1978) ${ }^{8}$.

Teisès doktrinoje nustatyta, kad visuotinai pripažinti teisès principai atlieka svarbias funkcijas. Teisès principai taikomi reglamentuojant teisinius santykius, juos aiškinant, užpildant reglamentuojančių teisès aktų spragas ir šalinant kolizijas ${ }^{9}$. Ka-

2 Alphabetical list of ILO member countries (185 countries) [interaktyvus]. International labour organization [žiūrèta 2014-04-27]. <http://www.ilo.org/public/english/standards/relm/ country.htm>.

32006 m. Konvencija dèl darbo jūrų laivyboje. Valstybès žinios. 2013, Nr. 78-3941.

4 Ratifications of MLC - Maritime Labour Convention, 2006 [interaktyvus]. International labour organization [žiūrèta 2014-04-27]. <http://www.ilo.org/dyn/normlex/en/f?p=NORMLEXPUB :11300:0::NO::P11300_INSTRUMENT_ID:312331>.

5 Išduotų dokumentų statistika [interaktyvus]. Lietuvos saugios laivybos administracija [žiūrèta 2014-04-27]. <http://www.msa.lt/lt/papildomas-meniu/statistine-informacija_702/isduotu-doku mentu-jurininkams-statistika.html $>$.

$61973 \mathrm{~m}$. Tarptautine konvencija dèl teršimo iš laivų prevencijos, papildyta $1978 \mathrm{~m}$. protokolu. Valstybès žinios. 2004, Nr. 138-5030.

$71974 \mathrm{~m}$. Tarptautinè konvencija dèl žmogaus gyvybès apsaugos jūroje. Valstybès žinios. 2006, Nr. 128-4887.

81978 m. Tarptautinè konvencija dèl jūrininkų rengimo, atestavimo ir budejjimo normatyvų. Valstybès žinios. 2005, Nr. 10-325.

9 Pakalniškis, V., et al. Civiline teisè. Bendroji dalis. I tomas. Vilnius: Lietuvos teisès universitetas, 2004, p. 57. Mikelènas, V., et al. Lietuvos Respublikos civilinio kodekso komentaras. Pirmoji 
dangi būtent teisès principai norminius teisès aktus vienija ị vieną darnią sistemą, kurios tikslas - teisingumo įtvirtinimas, yra būtinybe išanalizuoti anksčiau priimtų jūrininkų darbo teisnius santykius reglamentuojančiu norminių teisès aktų suderinamumą su $2006 \mathrm{~m}$. Konvencijos dèl darbo jūrų laivyboje nuostatomis per bendrų ir darbo teisès principų prizmę.

Anksčiau iškeltas tikslas reikalauja atlikti šiuos uždavinius. Pirma, išanalizuoti bendrųjų ir darbo teisès principų įtvirtinimą 2006 m. Konvencijoje dèl darbo jūrų laivyboje. Antra, išanalizuoti Lietuvos norminius teisès aktus, reglamentuojančius darbą jūrų laivyboje. Trečia, nustatyti, ar nèra kolizijų tarp iki 2006 m. Konvencijos dèl darbo jūrų laivyboje įsigaliojimo priimtų norminių teisès aktų ir minètos Konvencijos.

Dokumentų analizè yra pagrindinis straipsnio mokslinio tyrimo metodas. Straipsnyje taip pat taikomi loginès analizès, sisteminès analizès, sintezès, lingvistinis (gramatinis) ir lyginamasis metodai.

Lietuvos teisès doktrinoje iki šiol nebuvo analizuojama jūrininkų, kaip ypatingos darbuotojų kategorijos, teisinè padètis. Straipsnyje analizuojama Lietuvos ir užsienio mokslinè literatūra, nagrinėjanti darbo santykių teorinius ir praktinius aspektus.

\section{MLC 2006 taikymo bendrieji klausimai}

Gamybinio proceso specifika jūrų transporte lemia tai, kad jūrininko darbas susijęs su ypatingomis rizikomis. Tarp jų yra ne tik grynai technologiniai veiksniai, t. y. tiesioginè technologinių kompleksų ir mechanizmų priežiūra, bet ir gamtos veiksniai, t. y. oro sąlygos ir dažna jų kaita, ịvairūs kataklizmai ir t. t. Darbo teisniai santykiai jūrų transporte pradèti reglamentuoti nuo XIX a. pradžios ${ }^{10}$. Laikui bègant, jūrininkų darbo ir profesinių susirgimų rizika nesumažèjo, todèl po Antrojo pasaulinio karo pradèta aktyviai diskutuoti apie jų, kaip ypatingos profesinès ir socialinès grupés, darbo ir gyvenimo sąlygų ypatingą pobūdį ${ }^{11}$. Jūreivių darbo profesinių susirgimų ir nelaimingų atsitikimų rizikos sumažinimas įmanomas tik pasitelkiant tarptautinès bendruomenès pagalbą ${ }^{12}$. Tarptautinès bendruomenès ir tarptautinių organizacijų, iš kurių pagrindinị vaidmenį nagrinejjamoje srityje vaidina TDO, pastangomis buvo priimta daugelis konvencijų ir rekomendacijų, turinčių tikslą užtikrinti žmogaus teises vykdant komercinę-ūkinę veiklą jūroje. MLC 2006 prièmimas ir įsigalioji-

knyga. Vilnius: Justitia, 2001, p. 59-62; Nekrošius, I., et al. Lietuvos Respublikos darbo kodekso komentaras. Pirmas tomas. Vilnius: Justitia, 2003, p. 21.

10 Mačernytė-Panomariovienė, I. Tarptautinių darbo laivuose standartų ịtaka Lietuvos jūrininkų darbo santykiams. Jurisprudencija. 2007 1(91): 34.

11 Evang, K. Health and Welfare of Seafarers: An International problem. International labour review.1951, LXIII (1): 2.

Ibid., p. 3. 
mas atverčia naują puslapi prekybinejje laivyboje. Atsižvelgiant ị šios Konvencijos X straipsnị, galima ją pavadinti „Jūrininkų darbo kodeksu“. Minètas straipsnis nustato, kad po MLC 2006 ịsigaliojimo peržiūrimos iš viso trisdešimt septynios konvencijos. Iš jų galima ịvardinti tokias svarbias, kaip 1926 m. Konvencija dèl jūrininkų darbo sutarčių (Nr. 22), 1926 m. Konvencija dèl jūrininkų repatriacijos (Nr. 23), $1936 \mathrm{~m}$. Konvencija dèllaivų savininkųatsakomybės jūrininkųligosir sužalojimųatveju (Nr. 55), 1936 m. Konvencija dèl jūrininkų ligos draudimo (Nr. 56), 1946 m. Konvencija dèl laivų ígulos maisto ir maitinimo (Nr. 68), 1946 m. Konvencija dèl jūrininkų sveikatos patikrinimo (Nr. 73), 1946 m. Konvencija dèl darbo užmokesčio, darbo laiko jūroje ir igulos komplektavimo (Nr. 76), 1958 m. Konvencija dèl darbo užmokesčio, darbo laiko jūroje ir igulos suformavimo (pataisyta) (Nr. 109), 1987 m. Konvencija dèl jūrininkų sveikatos apsaugos ir priežiūros (Nr. 164) ir kt.

Kita vertus, Konvencijos kūrèjai pasirinko gana sudėtingą šio dokumento struktūrą. Konvencija susideda iš trijų atskirų, bet susijusių dalių, t. y. straipsnių, taisyklių ir kodekso ${ }^{13}$. Kodèl pasirinkta tokia sudetinga struktūra? Manytina, kad atsakymą gali duoti požiūris ị tarptautinę prekybinę laivybą kaip ị turinčią du svarbius ir sąveikaujančius tarpusavyje elementus. Pirmas segmentas yra vadinamasis idealusis (subjektyvusis). Jame atsispindi teisiniai santykiai tarp transporto proceso dalyvių, t. y. tarp vežejų, laivų savininkų, krovinio siuntėjų, krovinio savininkų, ekspeditorių ir t. t. Minètų teisinių santykių reglamentavimas yra konservatyvus, nusistovèjęs, keičiamas arba papildomas labai retai. Šią išvadą patvirtina trumpa tarptautinių transporto konvencijų ịsigaliojimo analizè. Pvz., 1980 m. Jungtinių Tautų konvencija dèl krovinių tarptautinio multimodalinio pervežimo neįsigaliojo iki šiol ${ }^{14}$. Analoginè situacija yra susiklosčiusi su 2008 m. Jungtinių Tautų konvencija dèl tarptautinio krovinių pervežimo jūra ar jos dalimi sutarties ${ }^{15}$ bei 1991 m. Jungtinių Tautų konvencija dèl transporto terminalų operatorių atsakomybės tarptautinejje prekyboje ${ }^{16}$. Antrasis segmentas yra vadinamasis technologinis (objektyvusis), jame greitai vystosi ir keičiasi technologijos. Jo vystymasis priklauso nuo gamtos mokslų raidos ir inžinerinès minties pažangos. Naujų mechanizmų, automatinių prietaisų panaudojimas prekybinejje laivyboje leidžia darbuotojams reikalauti geresnių darbo ir gyvenimo sąlygų. Kita vertus, jūreiviai, kaip visuomenès dalis, negali likti reikšmingų socialinès sferos pokyčių nuošalyje. Būtent dèl tos priežasties ir atsirado tiek daug įsigaliojusių konvencijų jūrininkų darbo ir socialinès apsaugos srityje. Kita vertus, darbuotojų (jūrininkų) teisių užtikrinimo procesas negali būti užbaigtas ir minètų konvencijų arba

132006 m. Konvencija dèl darbo jūrų laivyboje. Valstybès žinios. 2013, Nr. 78-3941.

14 United Nations treaty collection [interaktyvus]. United Nations, 2014 [žiūrèta 2013-12-27]. $<$ https://treaties.un.org/Pages/ViewDetails.aspx?src=TREATY\&mtdsg_no=XI-E-1\&chapter= 11\&lang=en $>$.

15 Ibid.

16 Ibid. 
jų pakeitimų gali atsirasti dar daugiau. Konvencijos kūrẻjai teisingai ịvertino bendras socialinio dialogo tendencijas, atsižvelge ị tai, kad darbo teisinius santykius jūrų laivyboje reglamentuojantys tarptautinès teisès dokumentai turi vystytis dinamiškai, neatsiliekant nuo techninès pažangos, kuri visiems technologinio proceso dalyviams suteikia papildomą komfortą socialinèje sferoje, ir pasirinko šią Konvencijos struktūrą.

Kita vertus, tarp mokslininkų jau seniai vyko diskusijos dèl būtinybės kodifikuoti darbo konvencijas dviejuose ar trijuose darbo kodeksuose ${ }^{17}$. Taigi, kyla klausimas, kodèl reikejo išskirti straipsnius, taisykles ir kodeksą? Atsakymas duodamas MLC 2006 XIV ir XV straipsniuose. Konvencijos pakeitimo procedūra yra sudètingesnè, palyginti su kodekso pakeitimu, ji gali būti pakeista Tarptautinès darbo organizacijos Generalinės konferencijos pagal Tarptautinès darbo organizacijos ịstatų 19 straipsni. Kita vertus, pakeisti kodeksą gali siūlyti bet kurios Organizacijos narès vyriausybé, grupé laivų savininkų atstovų arba grupé jūrininkų atstovų, paskirtų ị MLC 2006 XIII straipsnyje nurodytą Komitetą. Vyriausybés teikiamus pakeitimus turi būti pasiūliusios arba paremusios bent penkių šią Konvenciją ratifikavusių Organizacijos narių vyriausybès arba šioje dalyje minètų laivų savininkų ar jūrininkų atstovų grupè. Akivaizdu, kad kodekso pakeitimo procedūra lankstesnè ir labiau atitinka jūrininko socialinių interesų tenkinimo poreikio dinamiką.

MLC 2006 denonsavimas yra nustatytas jos IX straipsnyje. Pasakytina, kad TDO narè, ratifikavusi MLC 2006, gali ją denonsuoti tik praẻjus dešimčiai metų nuo Konvencijos įsigaliojimo dienos. Taip užtikrinamas minètos Konvencijos taikymo stabilumas. Nors yra nuomonių, kad MLC 2006 ịsigaliojimas pabrangins transporto proceso dalyvių, t. y. laivų savininkų, frachtuotojų ir kt. sąnaudas ${ }^{18}$, ir su tuo reikia sutikti, galima išskirti ir teigiamą dalyką - dabar darbdaviai galès tiksliau numatyti ir planuoti savo išlaidas, susijusias su darbuotojų teisètų interesų užtikrinimu.

MLC 2006 įdomi ir tuo, kad ne visos jos normos yra imperatyvinès. Jos II straipsnio 1 dalies e) punktas nustato, kad Konvencijos reikalavimai yra jos straipsnių, taisyklių ir šios Konvencijos kodekso A dalies reikalavimai. Analoginè nuostata yra ir Konvencijos aiškinamojo rašto, pridèto prie Konvencijos dèl darbo jūrų laivyboje taisyklių ir kodekso ${ }^{19} 4$ punkto, kuriame nurodyta, kad Kodeksą sudaro A dalis (privalomi standartai) ir B dalis (neprivalomos gairès). Atsižvelgiant ị trumpą jūrininkų teisių užtikrinimo dinamikos analizę, darytina išvada, kad B dalis yra tam tikras orientyras, prie kurio turi judèti kiekviena valstybė - TDO nare - ir anksčiau ar vèliau $\mathrm{B}$ dalies taisyklès su atitinkamais pakeitimais ir patobulinimais virs imperatyvu.

17 Li, K. X.; Ng, J. M. International maritime conventions: seafarers' safety and human rights. Journal of Maritime Law \& Commerce. 2002, 33(3): 400.

18 Bauer, P. J. The Maritime Labour Convention: An Adequate Guarantee of Seafarer Rights, or an Impediment to True Reforms? Chicago Journal of International Law. 2007-2008, 8(2): 657. 2006 m. Konvencija dèl darbo jūrų laivyboje, supra note 13. 
Nustatant MLC 2006 taikymo ribas svarbu išsiaiškinti ne tik jos vienų ar kitų nuostatų priskyrimą prie imperatyvinių normų, bet ir asmenų, kurių atžvilgiu minèta Konvencija turi būti taikoma, ratą. MLC 20061 straipsnio 2 dalyje pateikiama bendra taisyklè: "Jei nenustatyta kitaip, ši Konvencija taikoma visiems jūrininkams." MLC 20061 straipsnio 1 dalies i) punkte pateikiama laivų, kuriems keliami reikalavimai šioje Konvencijoje, sąvoka. I ją j̣eina visi laivai, išskyrus tuos, kurie plaukioja išimtinai vidaus vandenyse arba uždaruose vandenyse, arba labai arti jų, arba teritorijose, kuriose galioja uosto taisyklès. Kita vertus, minèto straipsnio 4 dalis konkretizuoja, kad Konvencija taikoma ir valstybiniams, ir privatiems laivams, kurie paprastai naudojami komercinejje veikloje. MLC 2006 netaikoma žvejybos ar panašios paskirties laivams, tradicinès konstrukcijos laivams, karo laivams ir karinio laivyno pagalbiniams laivams.

Lietuvoje laivo sąvoka nustatyta dviejuose pagrindiniuose jūrinę laivybą reglamentuojančiuose teisès aktuose, t. y. Lietuvos Respublikos saugios laivybos ịstatymo 2 straipsnio 9 dalyje $^{20}$ ir Lietuvos Respublikos prekybinès laivybos ístatymo 2 straipsnio 17 dalyje $\mathrm{e}^{21}$. Abiejuose įstatymuose laivo sąvoka apibrěžta vienodai: „Laivas - bet kurio tipo savaeigis ar nesavaeigis plaukiojantis statinys, kuris yra arba gali büti naudojamas laivybai." Taigi, iš pirmo žvilgsnio, nustatant objekto priklausomybę laivų kategorijai, diskusijų neturi kilti, bet jos atsiranda dèl nesavaeigių naftos gręžimo platformų priskyrimo laivų kategorijai. Manome, kad šiuo atveju reikia analizuoti visus norminius įstatymus ir aiškinti visas sąvokas sistematiškai. Kaip jau minèta, rengiant MLC 2006 remtasi jau galiojančiomis konvencijomis, kurios reglamentuoja jūrininkų darbo veiklą. Taigi, sprendžiant nesavaeigių naftos ir kitų angliavandenių gręžimo platformų priskyrimo laivų kategorijai problemą MLC 2006 taikymo kontekste, reikia atsižvelgti ị MARPOL 73/78 2 straipsnio 4 punktą, kur nustatyta, kad „laivas reiškia bet kokio tipo laivą, naudojama jūros aplinkoje, ir apima laivus su povandeniniais sparnais, laivus su oro pagalve, galinčius veikti po vandeniu, arba plüdinius aparatus ir stacionarias arba plaukiančias platformas“. 1972 m. Tarptautinès konvencijos dèl Tarptautinių taisyklių, padedančių išvengti laivų susidūrimų jūroje (toliau - COLREGs) 3 taisyklèje nustatyta, kad praktiškai visi aparatai, kurie gali būti naudojami kaip vandens transporto priemonès, priskiriami laivų kategorijai $^{22}$. Atsižvelgiant ị tai, kas išdèstyta, manytina, kad šios MLC 2006 taisyklès turi

20 Lietuvos Respublikos saugios laivybos ịstatymas. Valstybès žinios. 2000, Nr. 75-2264.

21 Lietuvos Respublikos prekybinès laivybos ịstatymas. Valstybès žinios. 1996, Nr. 101-2300.

22 International Regulations for Preventing Collisions at Sea [interaktyvus]. Lloyd's Register Rulefinder, 2005 [žiūrèta 2014-04-27]. <http://www.mar.ist.utl.pt/mventura/Projecto-NaviosI/IMO-Conventions\%20(copies)/CO LREG-1972.pdf>; JTO konvencijos, kuriose dalyvauja Lietuva [interaktyvus]. Lietuvos saugios laivybos administracija [žiūrèta 2014-04-27]. <http:// www.msa.lt/lt/teisine-informacija/teises-aktai/tarptautiniai-susitarimai-saugios-9qyq/ tarptautines-juru-organizacijos-konvencijos/tarptautines-juru-organizacijos-9ev8/864/ p0.html>. 
būti taikomos ir darbininkams, dirbantiems nesavaeigèse naftos ir kitų angliavandenilių gręžimo platformose, kadangi jos buksyruojamos ir gali būti naudojamos kaip vandens transporto priemonés. Po laivo statuso nustatymo svarbus klausimas, kuri reikia išspręsti, taikant MLC 2006, yra asmens priskyrimo jūrininkų kategorijai. MLC 20061 straipsnio 1 dalies f) punkte pateikiama jūrininko MLC 2006 taikymo prasme sąvoka. Taigi, jūrininkas - bet kuris asmuo, ịdarbintas, pasamdytas, ar einantis bet kokias pareigas laive, kuriam taikoma MLC 2006. Lietuvos Respublikos saugios laivybos įstatyme nẻra pateikta jūrininko sąvoka, bet yra pateikti laivo ịgulos, laivavedžio ir laivo kapitono sąvokų apibrèžimai. Taigi, „laivo igula - laivo kapitonas ir kiti jūrininkai, atliekantys laive užduotis, susijusias su laivo eksploatavimu ar aptarnavimu, ir įrašyti laivo igulos saraše“ (Lietuvos Respublikos saugios laivybos ịstatymo 2 str. 11 d.). Lietuvos Respublikos prekybinès laivybos ịstatymo 2 straipsnio 10 dalyje konkretizuojama: „jürininkas - laivo igulos narys, pasamdytas darbui laive“. Taigi, įvertinus šių dviejų i̊statymų nuostatas, peršasi išvada, kad reikalauti taikyti MLC 2006 savo santykiams su darbdaviu gali tik tas jūrininkas, kuris: a) pasamdytas darbui laive; b) įrašytas ị igulos sąrašą.

Galima tvirtinti, kad Lietuvos Respublikos prekybinès laivybos ịstatymo 2 straipsnio 10 dalyje pateikiama jūrininko definicija yra plati ir iš esmès atitinka MLC 2006 1 straipsnio 1 dalies f) punkte pateikiamą sąvoką, bet kaip išspręsti situaciją, kurioje kilo konfliktas tarp darbdavio ir darbuotojo, pasamdyto dirbti laive, bet neįrašyto ị laivo ịgulos sąrašą? Ši situacija nèra dirbtinai sugalvota. Taip dažnai atsitinka, kai laivo valdytojas savo įmonés jegomis atlieka nedidelị laivo remontą registracijos uoste. Reikia pripažinti, kad dèl objektyvių priežasčių Lietuvoje kol kas nẻra teismų praktikos, kuri konkretizuotų atsakymą ị šị klausimą, todèl būtina apžvelgti, kaip šis klausimas spendžiamas kitose valstybèse.

$J A V$. Ši valstybè neratifikavo MLC $2006^{23}$, kita vertus, čia jūreivio statuso nustatymas darbuotojui turi didelę reikšmę jo interesų gynimui, kadangi nuo jūreivio statuso priklauso, ar darbuotojas galès pasinaudoti socialinemmis garantijomis, kurias suteikia bendroji teise šioje valstybejje ${ }^{24}$. Nuo 1991 metų JAV teismų praktika suformulavo kriterijus, pagal kuriuos darbuotojas priskiriamas jūrininkų kategorijai. Jie yra pakankamai aiškūs ir, atsižvelgiant ị Jūrų teisès universalumą bei tai, kad jūreivių profesija yra labiausiai mobili ir jie visada dalyvauja teisiniuose santykiuose, kurie turi tarptautinị elementą, būtina šiuos kriterijus trumpai apžvelgti. Taigi, asmuo gali

23 Ratification and implementation information for the Maritime Labour Convention, 2006 [interaktyvus]. International labour organization [žiūrèta 2014-04-27]. <http://www.ilo.org/ global/standards/maritime-labour-convention/database-ratification-implementation/lang--en/ index.htm_ $>$.

24 Robertson, D. W.; Sturley, M. F. Recent Developments in Admiralty and Maritime Law at the National Level and in the Fifth and Eleventh Circuits. Tulane Maritime Law Journal. 20122013, 37: 430 . 
būti pripažintas jūrininku ir naudotis šios profesijos atstovams suteikiamomis garantijomis, jeigu jis ${ }^{25}$ :

1) dirba laive, laivui arba savo darbu padeda užtikrinti laivo (arba grupès laivų) vykdomų funkcijų atlikimą. Šio reikalavimo turinį atskleidžia JAV Devintosios apygardos apeliacinis teismas byloje Heise v. Fishing Co. of Alaska ${ }^{26}$. Šioje byloje teismas nustatè, kad darbuotojas, kuris kad ir atliko laikinus darbus laive (pvz., remonto ir pan.), negali automatiškai būti pripažintas jūrininku. Teismas pasisakè, kad darbuotojo ryšys su laivu turi būti pakankamas ir glaudus, dèl ko jis patiria daugiau rizikos, natūraliai susijusios su buvimu ir darbu jūroje.

2) kitas reikalavimas yra susijęs su darbuotojo sąsaja su laivu ar kitu plaukiojančiu ịrenginiu navigacijos metu. Bet darbuotojai, kurie plaukia laivu ị kitą objektą ar įrenginį be jūrininkų ar neturi atlikti darbo funkcijų, neatitinka šio reikalavimo. Ši taisyklè vadinama vessel in navigation (angl.) ir išaiškinta tokiose bylose, kaip DiGiovanni v. Traylor Bros., Inc. ${ }^{27}$ ir Estate of Wenzel v. Seaward Marine Services, Inc. ${ }^{28} \mathrm{Kita}$ vertus, šio standarto išaiškinimas pateiktose bylose leidžia tvirtinti, kad JAV teismų praktika jūrininkų statusą suteikia darbuotojams, dirbantiems plaukiojančiuose įrenginiuose šių ịrenginių navigacijos ar transportavimo metu, nors šių įrenginių paskirtis ir nèra krovinių ar keleivių vežimas jūra.

3) darbuotojo sąsaja su laivu turi būti neatsitiktinè, o tęstis pakankamai ilgą reikšmingą laikotarpi, t. y. turi būti tęstinè. Darbuotojo sumarinis darbas laive ar plaukiojančiame įrenginyje turi būti ne mažiau kaip 30 procentų jo viso darbo laiko. Šis standartas detaliai aprašytas byloje Roberts v. Cardinal Services ${ }^{29}$. Šioje byloje apeliacinès ir pirmosios instancijos teismai atsisakè tenkinti ieškovų reikalavimą ir pripažinti, kad vienas iš jų (šeimos galva Rusty Roberts) nelaimingo atsitikimo metu turejjo jūrininko statusą, ir atitinkamai nepripažinta ji turejjus teisę i žalos atlyginimą, taikytą jūrininkams pagal Džiono įstatymą (angl. Jones Act).

4) darbuotojo funkcijos turi būti natūraliai susijusios su darbu jūroje (angl. substantial in nature). Šio standarto esmè atskleista byloje In re Endeavor Marine, Inc. ${ }^{30}$

$25 \quad$ Ibid., p. 431.

26 Heise v. Fishing Co. of Alaska, Inc. (1996) 79 F.3d 903 [interaktyvus]. Leagle, Inc., 2014 [žiūrèta 2014-04-27]. <http://www.leagle.com/decision/199698279F3d903_1834>.

27 DiGiovanni v. Traylor Bros., Inc. (1st Cir. 1992) 959 F.2d 1119 [interaktyvus]. Leagle, Inc., 2014 [žiūrèta 2014-04-27]. <http://www.leagle.com/decision/19922078959F2d1119_11904>.

28 Estate of Wenzel v. Seaward Marine Services, Inc. (9th Cir. 1983) 709 F.2d 1326 [interaktyvus]. Leagle, Inc., 2014 [žiūrèta 2014-04-27]. <http://www.leagle.com/decision/19832035709F2d1326_ $11794>$.

29 Roberts v. Cardinal Services, Inc. (5th Cir. 2001) 266 F.3d 368 [interaktyvus]. Leagle, Inc., 2014 [žiūrèta 2014-04-27] . <http://leagle.com/decision/2001634266F3d368_1605>.

30 In re Endeavor Marine, Inc. (5th Cir. 2000) 234 F.3d 287 [interaktyvus]. Public. Resource. Org, Inc., 2014 [žiūrèta 2014-04-27 ]. <https://law.resource.org/pub/us/case/reporter/F3/234/234. F3d.287.99-30197.html>. 
Teismai išaiškino, kad pagal šią taisyklę darbuotojas turi būti natūraliai susijęs su laivu, o tai reiškia, kad jis nuolat arba pakankamai reikšmingą laiko tarpą susiduria su jūros keliamais pavojais ${ }^{31}$.

Didžioji Britanija. Didžiojoje Britanijoje MLC 2006 ịsigalioja nuo $2014 \mathrm{~m}$. rugpjūčio 7 d., bet jau dabar įsigaliojo 2013 metų Prekybinès jūrų laivybos (Konvencija dèl darbo jūrų laivyboje) (Siurvej ir sertifikavimas) reguliavimas ${ }^{32}$, kuris atspindi pagrindines MLC 2006 nuostatas. Minèto Reguliavimo 2 straipsnyje nustatyta, kad jūrininkas yra bet koks asmuo, įskaitant laivo kapitoną, kuris įdarbintas, pasamdytas ar eina bet kurias pareigas laive ir kurio normali darbo vieta yra laive.

Taigi, nesunku pastebėti, kad šiuo metu yra tam tikri neatitikimai tarp MLC 2006 ir 2013 metų Prekybinès jūru laivybos (Konvencija dèl darbo jūrų laivyboje) (Siurvej ir sertifikavimas) reguliavimo.

Pirma, remiantis prekybinès laivybos reguliavimu ị jūrininko definiciją patenka ir kapitono statusą turintis asmuo. Manytina, kad tai padaryta siekiant išvengti abejonių, kylančių dèl kapitono, kaip darbdavio atstovo, statuso santykiuose tarp darbdavio ir kitų jūrininkų.

Antra, čia nèra nuostatos, suteikiančios jūrininko statusą tik tiems asmenims, kurie dirba laivuose, kuriems, taikoma MLC 2006. Manytina, kad tai atspindi pereinamąji iki MLC 2006 issigaliojimo laikotarpi.

Trečia, reikalavimas „kurio normali darbo vieta yra laive“ yra panašus ị JAV jūrininkų statuso „tęstinumo“ ir „natūralios sąsajos“ kriterijus. Šių kriterijų apibrèžimas atspindi tikslą apriboti asmenų, galinčių pasinaudoti padidintomis jūrininkų garantijomis, statusą.

Vokietija. Nepaisant to, kad šioje šalyje MLC 2006 ịsigalios nuo $2014 \mathrm{~m}$. rugpjūčio $16 \mathrm{~d} .^{33}$, t. y. praejjus metams po ratifikavimo, Vokietija jau pradejjo taikyti šios Konvencijos nuostatas. MLC 2006 pasirašiusioms valstybèms palikta galimybe pačioms spręsti, kokiu būdu igyvendinti šią Konvenciją. 2013 m. rugpjūčio $1 \mathrm{~d}$. Vokietijoje i̊sigaliojęs Darbo jūroje isstatymas (vok. Seearbeitsgesetz ${ }^{34}$ ) perkèle ị Vokietijos teisę MLC 2006 nuostatas ir tokiu būdu pakeitè 1957 m. Jūrininkų i̇statymą (vok. Seemannsgesetz $\left.{ }^{35}\right)$. I naująji Darbo jūroje įstatymą ịejo aibẻ naujų normų: įrašytas i

31 Daniels, Chr. B. Admiralty law. Texas Tech Law Review. 2001-2002, 33: 552.

32 The Merchant Shipping (Maritime Labour Convention) (Survey and Certification) Regulations 2013 [interaktyvus]. UK legislation [žiūrèta 2014-01-24]. <http://www.legislation.gov.uk/ uksi/2013/1785/pdfs/uksi_20131785_en.pdf >.

33 Ratification and implementation information for the Maritime Labour Convention, 2006 [interaktyvus]. International labour organization [žiūrèta 2014-04-27]. <http://www.ilo.org/ global/standards/maritime-labour-convention/lang--en/index.htm >.

34 Gesetze im Internet [interaktyvus]. Bundesministerium der Justiy und für Verbraucherschuty [žiūrèta 2014-04-27] . <http://www.gesetze-im-internet.de/bundesrecht/seearbg/gesamt.pdf >.

35 Seemannsgesetz [interaktyvus]. Gesetze und Verordnungen des deutschen Bundesrechts im Internet [žiūrèta 2014-04-27 ]. <http://www.buzer.de/gesetz/470/>. 
laivo igulos sąrašą asmuo tiesiogiai iggyja ịstatymo garantuojamą socialinę apsaugą, laivo savininkai privalo sudaryti su jūrininkais naujas darbo sutartis, prailginti atlyginimo skyrimą ligos atveju bei nustatyti aiškiai suformuluotą skundų nagrinèjimo tvarką esant denyje. Be to, ateityje visi laivai privalès būti patikrinti darbo inspekcijos.

Naujojo įstatymo nuostatos yra taikomos visiems jūrininkams, įdarbintiems laivuose, plaukiojančiuose jūroje bei naudojamuose verslo tikslais. I i istatyme numatytų laivų sampratą taip pat patenka verslo žvejybos laivai. Vis dèlto pagal ịstatymo $\$ 1$ ị šią sąvoką nepatenka sportiniai laivai (jachtos), kurių ilgis nesiekia $24 \mathrm{~m}$ ir juose nèra įdarbinti daugiau kaip 2 asmenys. Tuo tarpu darbo santykiams, kylantiems laivuose, plaukiojančiuose vidaus vandenimis, o ne jūra, be bendrųjų darbo teisès nuostatų, galioja specialiosios, numatytos İstatymo dèl privačių santykių vidaus laivyboje $\$ 21-25^{36}$ (vok. Gesetz betreffend die privatrechtlichen Verhältnisse der Binnenschiffahrt $\left.{ }^{37}\right)$.

I jūrininko sąvoką patenka visi laive įdarbinti asmenys, tačiau neįeina asmenys, kurie tik laikinai atlieka darbus arba darbai yra neịprasti atlikti laive. Kaip pavyzdị galima pateikti darbuotojus, kurie ịrenginejja jūros vejjo turbinas.

Galiojant ankstesniajam Jūrininkų įstatymui (vok. Seemannsgesetz), ypatingajj statusą turejjo kapitonas ${ }^{38}$. Atsižvelgiant ị šio įstatymo $\$ 2$ ir $₫ 3$, kapitonas nebuvo priskirtinas laivo igulai. Jo tarnyba rèmėsi ypatinguoju kolektyviniu susitarimu, kuris apima susitarimą dèl kapitono darbo sąlygų ${ }^{39}$. Tuo tarpu naujojo Vokietijos darbo jūroje istatymo (vok. Seearbeitsgesetz) $\$ 51$ dalyje kapitonas yra priskirtas prie igulos.

\section{Bendrųjų ir darbo teisès principų konkretizavimas jūrininkų atžvilgiu remiantis MLC 2006}

Išanalizuoti visus teisès principus straipsnyje yra neįmanoma, kadangi tai yra ne tik visos teisinès sistemos pamatas, bet ir demokratinès visuomenès egzistavimo pagrindas. Tradiciškai teisinè doktrina teisès principus supranta kaip vadovaujantị pradą, išreiškiantị esminius visuomeninių santykių bruožus, jų raidos tendencijas,

36 Lindemann, D.; Bemm, W. Seemannsgesetz und Manteltarifvertrag für die deutsche Seeschiffahrt. 6. Auflage. Becker, 2007, p. 145.

37 Gesetze im Internet [interaktyvus]. Bundesministerium der Justiy und für Verbraucherschuty [žiūrèta 2014-04-27]. <http://www.gesetze-im-internet.de/binschprg/BJNR003010895.html>.

38 Kompass September/Oktober 2013, p. 4 [interaktyvus]. Knappschaft Bahn See [žiūrèta 201404-27]. <http://www.kbs.de/DE/00_ueber_uns/33_bottom_nav/05_kompass_archiv/ausgabe_ 2013_09_10.html >.

39 Puttfarken, H. J. Seehandelsrecht. Heidelberg: Verlag Recht und Wirtschaft GmbH, 1997, p. 225 . 
bendro teisino reguliavimo turinị ir tikslus ${ }^{40}$. Pateikti bendrų teisès principų baigtinị sąrašą yra neimmanoma, kadangi visuomenè vystosi, jos evoliucija lemia tai, kad šie principai taip pat keičiasi. Kita vertus, jie visada atitinka arba turi atitikti pagrindinius reikalavimus, ịtvirtintus net mūsų pozityviojoje teiseje, t. y. teisingumo, protingumo ir sąžiningumo reikalavimus (CK 1.5 str. 1 d.).

Darbo teisės principai, kaip šakiniai teisès principai, teisės doktrinoje tradiciškai skirstomi ị: a) pasaulinius ir regioninius; b) nacionalinius ${ }^{41}$. Manytina, kad po MLC 2006 ratifikavimo ir įsigaliojimo šioje Konvencijoje ittvirtinti teisès principai tapo ne tik pasauliniai, bet ir nacionaliniai. Taigi dabar yra aktualu padaryti šiu principu trumpą analizę ir ịvertinti, ar jų turinys atitinka darbo teisès principus, ịtvirtintus Lietuvos teisès norminiuose aktuose iki šios Konvencijos ịsigaliojimo.

Kaip jau pažymèta, darbo teisès principai negali prieštarauti teisingumo principui, kaip pamatiniam šiuolaikinès visuomenès principui. Kita vertus, reikia pritarti Brian A. Langille nuomonei, kad darbo teisès ir darbuotojų teisèti interesai yra ekonominio vystymosi kaina ir kliūtis ${ }^{42}$. Pagrindinis klausimas - ar galima surasti kompromisą tarp ekonominés pažangos ir žmogaus teisių bei kaip išvengti prieštaravimo tarp verslo veiklos tikslo, t. y. maksimalaus pelno siekimo, ir pagrindinių žmogaus teisių užtikrinimo? Manytina, kad galima ir reikia taip pat ir šį tikslą pasiekti būtent pagrindinių darbuotojų teisių ir standartų užtikrinimu. Pasak Brian A. Langille, jų išskyrimas ir ịtvirtinimas padeda suprasti darbuotojų teisių ir ekonominio vystymosi dichotomiją ${ }^{43}$.

1998 metais Deklaracijoje dèl pagrindinių principų ir teisių darbe ${ }^{44}$ TDO ịtvirtino darbo teisių hierarchiją ir pamatinėmis darbuotojų teisèmis įvardijo šias: a) asociacijų laisvè ir veiksmingas teisès ị kolektyvines derybas pripažinimas; b) visų priverstinio ar privalomojo darbo formų panaikinimas; c) veiksmingas vaikų darbo panaikinimas ir d) su užimtumu ir profesija susijusios diskriminacijos panaikinimas. Pažymètina, kad pati MLC 2006 jūrininkų teises skirsto į pagrindines teises ir principus (MLC 2006 III str.). Šių teisių ir principų apibrèžimas atitinka 1998 metais priimtos Deklaracijos dèl pagrindinių principų ir teisių darbe bei jūrininkų darbo ir

40 Tiažkijus, V. Darbo teisè: teorija ir praktika. I tomas. Vilnius: Justitia, 2005, p. 63; Jankauskas, K. Teisès principų samprata ir jų formulavimo teisès aiškinimo aktuose ypatumai. Jurisprudencija. 2004, 51 (43): 21.

41 Tiažkijus, V., supra note 40, p. 64-66.

42 Leary Waner, D., et. al. International Studies in Human Right, Volume 84: Social Issues, Globalization and International Institution: Labor Right and the EU, ILO, OECD and WTO. Leiden, NLD, 2005, p. 99.

43 Ibid., p. 101.

44 ILO Declaration on Fundamental Principles and Rights at Work and its Follow-up [interaktyvus]. International labour organization [žiūrèta 2014-04-27]. <http://www.ilo.org/declaration/ thedeclaration/textdeclaration/lang--en/index.htm >. 
socialinių teisių apibrèžimą (MLC 2006 IV str.). Taigi, jūrininkų darbo ir socialinių teisių apžvalga pateikiama šia tvarka.

\subsection{Pagrindinių teisių ir principų, ittvirtintų MLC 2006 III straipsnyje, apžvalga}

Kaip jau minèta, MLC 2006 pagrindinių teisių ir principų apibrèžimas atitinka 1998 metų Deklaraciją dèl pagrindinių principų ir teisių darbe. Pačioje Konvencijoje neatskleidžiamas jos III straipsnyje nustatytų teisių ir principų turinys, bet nesunku pastebėti, kad tarp jų ir MLC 2006 IV straipsnio taip pat yra tam tikras glaudus ryšys, kuris pasireiškia tuo, kad ketvirtojo straipsnio nustatytos darbo ir socialinès teisès konkretizuoja ir pagrindines teises ir principus. Atskirai reikètų pasisakyti dèl jūrininkų teisių i asociacijų laisvę ir veiksminga teisés i kolektyvines derybas pripažinimą (MLC 2006 III str. a) p.). Lietuvos Respublikos darbo kodekse ${ }^{45}$ (toliau DK) šis principas yra išskiriamas į du atskirus principus, t. y. ị asociacijų laisvę (DK 2 str. 1 d. 1) p.) ir kolektyviniu derybų laisvę siekiant suderinti darbuotojų, darbdavių ir valstybés interesus (DK 2 str. 1 d. 10) p.). Lietuvos Respublikos Konstitucijos 35 str. ${ }^{46}$ nustatyta, kad piliečiams laiduojama teisè vienytis ị bendrijas, politines partijas ir asociacijas, jei šių tikslai ir veikla nèra priešingi Konstitucijai ir ịstatymams. Mūsų teisinejje doktrinoje vyrauja nuomonè, kad socialinė partnerystè, kaip sistema, grindžiama ir laisvomis kolektyvinemis derybomis. Doc. dr. Viktoras Tiažkijus pažymejo, kad šis principas taip pat yra ir tarptautinis principas, kuris yra ittvirtintas tarptautinejje teisèje, ir Lietuva įsipareigojo taikyti ši principą, t. y. „savo nacionalinès teisès normomis nevaržyti darbuotoju ir darbdavių laisvès kurti vietines, nacionalines ar tarptautines organizacijas savo ekonominiams ar socialiniams interesams ginti ir stoti $i$ šias organizacijas arba netaikyti nacionalinès teisès normu taip, kad varžytu šią laisvę (...). " 47 Taigi, galima tvirtinti, kad šiuo metu galiojanti Lietuvos pozityvioji teisė visiškai užtikrina asociacijos laisvę ir veiksmingą teisès ị kolektyvines derybas pripažinimo vykdymą. Reikia pasakyti, kad MLC2006 nẻra specialiųjų teisès normų, konkretizuojančių šio principo turinị, skirtų jūrininkams, todèl šiai kategorijai darbuotojų minètu aspektu taikomi kiti Lietuvos norminiai teisès aktai.

MLC 2006 III straipsnio b) ir c) punktuose yra įvardinti visu priverstinio ar privalomojo darbo formu panaikinimo ir veiksmingo vaiku darbo panaikinimo principai. Šie principai yra pamatiniai ir ịtvirtinti ne tik Lietuvos Respublikos Konstitucijoje (Lietuvos Respublikos Konstitucijos 48 str.), bet ir tokiuose tarptautinès teisès aktuose, kaip Europos teisių ir pagrindinių laisvių apsaugos konvencija (minètos Konven- 
cijos 4 str. $^{48}$ ), TDO konvencija Nr. 29 „Dél priverstinio ar privalomojo darbo“49, TDO konvencija Nr. 105 „Dèl priverstinio darbo panaikinimo" ${ }^{\text {(50, }}$, TDO konvencija Nr. 79 "Dèl vaikų ir jaunuolių naktinio darbo apribojimo nepramoniniuose darbuose " ${ }^{\text {" } 1 \text {, }}$ TDO konvencija Nr. 182 „Dèl nepriimtino vaikų darbo uždraudimo ir neatidèliotinų veiksmų tokiam darbui panaikinti“"52 ir kt. Šie principai atitinka DK 4 straipsnio 1 dalies 2) punktą, 5) punktą ir 7) punktą. Kita vertus, šių principų papildomas akcentavimas šioje Konvencijoje yra būtinas dèl jūrininkų darbo specifikos ir sąlygų, kurioms yra būdingas šių darbuotojų atitraukimas nuo savo šalių valstybinių institucijų, ginančių darbuotojų teises. Uždaruose kolektyvuose, veikiančiuose autonomiškai (pvz., laivų igulos), ypatingą vaidmenị igyvendinant pagrindines teises ir principus darbuotojų atžvilgiu vaidina darbdavio administracija arba kiti jo atstovai, pvz., laivų kapitonai, kitų asmenų atžvilgiu tokị vaidmenį vaidina visa ịgula. MLC 2006 V straipsnio 1 dalyje yra numatyta, kad kiekviena valstybė nare igyvendina ir vykdo istatymus ir kitus teisés aktus bei kitas priemones, kurias patvirtino, kad igyvendintu savo ịsipareigojimus pagal MLC 2006 dèl laivų ir jūrininkų, kurie patenka ị jų jurisdikciją. Taigi, kyla labai svarbus klausimas - kaip faktiškai valstybẻ gali užtikrinti šiu principų igyvendinimą. Manytina, kad be veiksmingos kontrolès sistemos to padaryti neįmanoma ir ypač svarbu šią kontrolę užtikrinti būtent laivo reiso metu. Pvz., 2013 metais vienas iš Lietuvos laivų savininkų susidūrẻ su problema, kurioje praverstų ne tik valstybès kontrolè, bet ir valstybès institucijų pagalba. I lietuvišką laivą pakrovimo metu Maroko Karalystejje neteistai pateko du asmenys, iš kurių vienas buvo akivaizdžiai nepilnametis. Asmenys laive buvo aptikti tik Latvijos uoste iškraunant krovini. Darome prielaidą, kad laivo igula galètu nuspręsti priversti šiuos asmenis „atidirbti“ maitinimą ar kitokiais būdais atlyginti žalą. Atsižvelgdami ị JTO vykdomą kovą su prekyba žmonemis, mes negalime tvirtinti, kad civilizuotų tautų pastangos užtikrinti visu priverstinio ar privalomojo darbo formu panaikinimo ir veiksmingo vaiku darbo panaikinimo principų taikymą dabar yra neaktualios. Kita vertus, ne tik valstybės kontroliuojančios institucijos, bet ir laivų savininkai ne visada turi galimybę operatyviai vykdyti igulos kontrolę, bet neabejotinai visi šie subjektai suinteresuoti minètų principų igyvendinimo užtikrinimu. Ši problema yra kompleksinè - ne tik techninio, bet ir socialinio pobūdžio. Iš vienos pusès, reikètų platinti techninių priemonių (stebejjimo, vizualinès kontrolès priemonių, leidžiančių iš nuotolio kontroliuoti faktinę padètị laive, ir t. t.) panaudojimą, iš kitos pusès, būtų stabdomas

48 Europos teisių ir pagrindinių laisvių apsaugos konvencija. Valstybès žinios. 1995, Nr. 40-987.

49 TDO konvencija Nr. 29 „Dèl priverstinio ar privalomojo darbo“. Valstybès žinios. 1996, Nr. 27-648.

50 TDO konvencija Nr. 105 „Dèl priverstinio darbo panaikinimo“. Valstybès žinios. 1996, Nr. 28-676.

51 TDO konvencija Nr. 79 „Dèl vaikų ir jaunuolių naktinio darbo apribojimo nepramoniniuose darbuose“. Valstybès žinios. 1996, Nr. 27-650.

52 TDO konvencija Nr. 182 „Dèl nepriimtino vaikų darbo uždraudimo ir neatideliotinų veiksmų tokiam darbui panaikinti“. Valstybés žinios. 2003, Nr. 49-2161. 
nuoseklus darbas su ịgula, nebūtų ịmanoma suformuluoti pastovių kolektyvų, kurių narių moralinès ir psichologinès savybès galètų būti patikrintos. Čia pasireiškia bendražmogiškieji principai, kurie turètų būti puoselèjami.

Kitas principas, ịvardintas MLC 2006 kontekste, yra su užimtumu ir profesija susijusios diskriminacijos panaikinimo principas (MLC 2006 III str. d) p.). Šis principas atitinka numatyto DK 2 straipsnio 1 dalies 4 punktą, kuriame ittvirtinta „darbo teisès subjektų lygybė nepaisant jų lyties, seksualinės orientacijos, rasės, tautybès, kalbos, kilmès, pilietybès ir socialinès padèties, tikèjimo, ketinimo turèti vaiką (vaikų), santuokinès ir šeiminès padèties, amžiaus, ịsitikinimų ar pažiūrų, priklausomybès politinėms partijoms ir asociacijoms, aplinkybių, nesusijusių su darbuotojų dalykinėmis savybėmis“. Mūsų teisèje šis principas irgi nèra naujovè, kadangi tai yra ir tarptautinis teisès principas, ir konstitucinis darbo teisès principas, doktrinoje vadinamas lygiateisiškumo principu ${ }^{53}$. Negalima nesutikti su V. Tiažkijaus nuomone, kad darbo subjektų lygiateisiškumo principas negali būti deklaratyvus, turi būti praktiškai igyvendintas ir gerbiamas ${ }^{54}$. Suprantama, kad šio principo realumas yra užtikrintas galimybe būti patrauktam teisinèn atsakomybèn ${ }^{55}$. Bet ir čia mes susiduriame su ta pačia problema - kaip užtikrinti šio principo ịgyvendinimą jūrininkų reiso metu. Manytina, kad šio principo analizè jo igyvendinimo aspektu gali būti atlikta dviem kryptimis: 1) jo igyvendinimo užtikrinimas valstybès mastu, tai yra viešasis aspektas; 2) šio principo ịgyvendinimas visuose ị šios valstybès jurisdikciją patenkančiuose kolektyvuose. Galima tvirtinti, kad Lietuvos norminiai teisès aktai tinkamai reglamentavo šį tarptautinès teisès principą ir iki šios Konvencijos ịsigaliojimo, t. y. mūsų teritorijoje yra pakankamai viešosios prievartos priemonių, kuriomis valstybè gali priversti juridinius ir fizinius asmenis laikytis numatytų taisyklių. Vis dèlto šios priemonès ne visada gali būti veiksmingos atkuriant nukentejusiojo nuo diskriminacijos asmens teises iki laivo arba jo paties grị̌imo ị Lietuvą. Priemonès gali būti vèl tos pačios - techninès (faktinès padèties laive kontrolè laivo reiso metu) arba sociologinès (švietejjiškas darbas su ịgulos nariais, drausminès atsakomybès priemonès ir t. t.).

\subsection{Jūrininkų darbo ir socialinių teisių (MLC 2006 IV str.) konkretizavimas MLC 2006 taisyklèse ir kodekse}

Konvencijos aiškinamojo rašto, pridedamo prie Konvencijos dèl darbo jūrų laivyboje taisyklių ir kodekso ${ }^{56}, 7$ punkte nustatyti trys svarbiausieji šios Konvencijos tikslai: 1) įtvirtinti tvirtą teisių ir principų rinkinị; 2) užtikrinti, kad TDO narès galètų

53 Nekrošius, I., et al., supra note 9, p. 26; Tiažkijus, V., supra note 40, p. 72 -75.

54 Ibid., p. 75.

55 Ibid., p. 75.

562006 m. Konvencija dèl darbo jūrų laivyboje, supra note 13. 
pakankamai lanksčiai igyvendinti tas teises ir principus; 3) Kodekso 5 dalies nuostatomis užtikrinti tinkamą teisių ir principų laikymąsi ir vykdymą. Minèto rašto 6 punkte aiškinama, kad kiekvienoje Kodekso dalyje yra grupès nuostatų, susijusių su konkrečia teise ar principu (arba vykdymo priemone 5 dalyje). Taisyklių ir standartų numeracija MLC 2006 kodekse suderinta. Taigi, pati MLC 2006 struktūra verčia ši dokumentą analizuoti per jūrininkų pagrindinių - darbo ir socialinių teisių - prizmę.

MLC 2006 IV straipsnio 1 dalyje yra nustatyta, kad visi jūrininkai turi teisę $i$ saugią ir saugos standartus atitinkančią darbo vietą. Pažymètina, kad nurodytas principas savo esme atitinka principą, itvirtintą DK 2 straipsnio 1 dalies 5 punkte (saugiu ir sveikatai nekenksmingų darbo sąlygų sudarymas). MLC 2006 IV straipsnio 1 dalies teisès normoje kalbama apie darbo saugos standartus. Manytume, kad reiktų trumpai aptarti, koks yra teisès principų ir teisès standartų santykis. Pritartina Brian A. Langille nuomonei, kad teisininkai praktikai dažniausiai nesureikšmina skirtumą tarp „teisès“ ir „standarto“, kuris greičiausiai yra gramatinio pobūdžio, darbo standartuose gali atsispindèti procedūrinis darbo teisių igyvendinimo aspektas ${ }^{57}$. Būtų galima pridurti, kad darbo standartai papildo, konkretizuoja darbo teisių turini. Akivaizdu, kad ịvertinti, ar jūrininkui yra užtikrinta teisè ị saugią darbo vietą, galima tik per tam tikrus kriterijus, arba standartus. Galima pridurti, kad standartų nustatymas turi ne tik procedūrinị pobūdị, bet ir technologinị, kadangi taip įmanoma nustatyti, kas būtent yra „saugos standartai, atitinkantys darbo vietą“. Lietuvoje darbuotojų darbo saugos klausimai reglamentuojami nacionalinės teisès norminiais teises aktais. Pvz., Lietuvos Respublikos darbuotojų saugos ir sveikatos ịstatymo ${ }^{58} 1$ straipsnio 1 dalyje skelbiama, kad minèto įstatymo paskirtis yra nustatyti nemažai nuostatų ir reikalavimų siekiant apsaugoti darbuotojus nuo profesinės rizikos ar tokią riziką sumažinti, darbuotojų saugos ir sveikatos reikalavimus, darbuotojų saugos ir sveikatos viešaji administravimą ir valstybės institucijų kompetenciją ir kt. Lietuvos Respublikos nelaimingų atsitikimų darbe ir profesinių ligų socialinio draudimo i̊statymas $^{59}$ reglamentuoja nelaimingų atsitikimų darbe, profesinių ligų socialinio draudimo santykius, darbuotojų ir kitų asmenų teisę ị šio draudimo išmokas, išmokų skyrimo, apskaičiavimo bei mokejjimo sąlygas, apibrěžia draudžiamuosius ir nedraudžiamuosius ịvykius. Manytina, kad jūrininkų atžvilgiu minètus tikslus leidžia pasiekti būtent MLC 2006 nuostatos. Kita vertus, jei sausumoje negalima viename norminiame teisès akte išspręsti tiek daug technologinio, medicininio, socialinio pobūdžio problemų, tuo labiau to negalima padaryti ir reglamentuojant jūrininkų dar-

57 Leary Waner, D., et. al., supra note 42, p. 114-115.

58 Lietuvos Respublikos darbuotojų saugos ir sveikatos ịstatymas. Valstybės žinios. 2003, Nr. 703170 .

59 Lietuvos Respublikos nelaimingų atsitikimų darbe ir profesinių ligų socialinio draudimo ìstatymas. Valstybès žinios. 2003, Nr. 114-5114. 
bo teisinius santykius. Šio papildomo reglamentavimo valstybės teritorijoje funkcijas atlieka poịstatyminiai norminiai teisès aktai, pvz., Lietuvos Respublikos Vyriausybès 2002 m. sausio 9 d. nutarimas Nr. 13 „Dẻl Lietuvos Respublikos darbuotojų saugos ir sveikatos komisijos nuostatu patvirtinimo" ${ }^{\text {"60 }}$, Lietuvos Respublikos Vyriausybès 2003 m. rugsèjo 30 d. nutarimas Nr. 1195 „Dèl darbuotojų, kurių darbo pobūdis yra susijęs su didesne protine, emocine ittampa, darbo laiko sutrumpinimo tvarkos ir darbuotojų, kuriems nustatytas sutrumpintas darbo laikas, darbo apmokejjimo sąlygų patvirtinimo "61 ir kt. Su jūrininkais susijusias anksčiau minètas funkcijas daugeliu atvejų atlieka tarptautiniai dokumentai, pvz., $1982 \mathrm{~m}$. Jungtinių Tautų jūrų teisés konvencija $^{62}$, MARPOL 73/78, SOLAS 74, STCW 1978 ir kt. Kita vertus, Lietuvoje irgi yra priimti kai kurie ịstatymai ir poịstatyminiai teisės aktai, kurie konkretizuoja minètus tarptautinès teisès aktus. Pvz., Lietuvos Respublikos saugios laivybos įstatymas, Lietuvos Respublikos Vyriausybės 2006 m. gruodžio 6 d. nutarimas Nr. 1212 „Dèl Lietuvos Respublikos jūrininkų registro" ${ }^{63}$ ir kt. Manytina, kad principo visu jūrininku teisès ị saugią ir saugos standartus atitinkančią darbo vietą igyvendinimas negali būti perteklinis iš esmès, kadangi kaip sparčiai vystosi techninès priemonès, taip sparčiai turi vystytis ir būti diegiamos ịvairios priemonès, nustatančios naujus saugos standartus laivuose. Manytina, kad nebent tik patys pagrindinio Lietuvos teisinio norminio akto, t. y. Lietuvos Respublikos saugios laivybos ịstatymo, tikslai (Lietuvos Respublikos saugios laivybos įstatymo 1 str. 2 d.) neprieštarauja MLC 2006.

Kitas jūrininkų darbo ir socialinių teisių principas, ịtvirtintas MLC 2006 - visi jūrininkai turi teisę ị sąžiningas ịdarbinimo squlygas (MLC 2006 IV str. 2 d.). Minètas principas gali būti palygintas su principu, nustatytu MLC IV straipsnio 3 dalyje, - visi jūrininkai turi teisę i tinkamas darbo ir gyvenimo sąlygas laive. Pažymètina, kad nurodyti principai savo esme beveik atitinka principus, įtvirtintus DK 2 straipsnio 1 dalies 6-ame (teisingas apmokejjimas už darbą) ir 8-ame (darbo santykių stabilumas) punktuose.

Kaip MLC 2006 IV straipsnio 2 ir 3 dalių itvirtinti principai, taip ir DK 2 straipsnio 6 ir 8 punktų principai yra ne tik MLC 2006 ir darbo teisejje ịtvirtintos fundamentalios taisykless, bet ir Lietuvos konstituciniai (Lietuvos Respublikos Konstitu-

60 Lietuvos Respublikos Vyriausybès 2002 m. sausio 9 d. nutarimas Nr. 13 „Dèl Lietuvos Respublikos darbuotojų saugos ir sveikatos komisijos nuostatų patvirtinimo“. Valstybès žinios. 2002, Nr. 4-97.

61 Lietuvos Respublikos Vyriausybès 2003 m. rugsèjo 30 d. nutarimas Nr. 1195 „Dèl darbuotojų, kurių darbo pobūdis yra susijęs su didesne protine, emocine ịtampa, darbo laiko sutrumpinimo tvarkos ir darbuotojų, kuriems nustatytas sutrumpintas darbo laikas, darbo apmokejjimo sąlygu patvirtinimo“. Valstybès žinios. 2003, Nr. 93-4205.

621982 m. Jungtinių Tautų jūrų teisès konvencija. Valstybės žinios. 2003, Nr. 107-4786.

63 Lietuvos Respublikos Vyriausybès 2006 m. gruodžio 6 d. nutarimas Nr. 1212 „Dèl Lietuvos Respublikos jūrininkų registro“. Valstybès žinios. 2006, Nr. 134-5082. 
cijos 48 str.), tarptautiniai (Visuotinès žmogaus teisių deklaracijos 23 str. $^{64}$, Europos socialinès chartijos (pataisytos) 2 str., 3 str. ${ }^{65} \mathrm{ir} \mathrm{kt}$.) teisès principai. Šių principu funkcijos yra užtikrinti jūrininkų socialines teises siekiant gauti dalị pridètinés vertès proporcingai jų indèliui gamybos procese. Kaip jau buvo minèta, Lietuvoje šie darbo teisès principai yra konkretizuojami ịvairiuose ịstatymuose ir poịstatyminiuose norminiuose teisès aktuose ${ }^{66}$. Šie principai jūrininkų atžvilgiu konkretizuoti ir MLC 2006 konvencijoje. Paskutinis jūrininkų darbo teisès principas, ịtvirtintas MLC 2006 IV straipsnio 4 dalyje, yra visu jūrininkų teisés $i ̣$ sveikatos apsaugą, sveikatos priežiūra, socialines gerbüvio priemones ir kitas socialinès apsaugos formas. Nors paskutiniais dešimtmečiais civilizuotose valstybėse skiriama pakankamai dèmesio darbuotojų socialinių interesų teisių apsaugai, vis dèlto reikia pripažinti, kad jūrininkų atžvilgiu tai padaryti buvo gana sudètinga būtent dèl objektyvių priežasčių, apie kurias jau buvo kalbèta (privatus tarptautinis teisinis elementas jūrininkų darbo santykiuose, viešųjų institucijų atitraukimas nuo darbo santykių kontrolès ir pan.). Todèl šio principo išskyrimas kaip atskiros kategorijos minètoje Konvencijoje yra logiškas ir suprantamas.

\subsection{Kai kurios MLC 2006 nustatytų jūrininkų darbo ir socialinių teisių igyvendinimo problemos}

MLC 2006 struktūra yra pažangi ir tuo, kad joje pateiktos ne tik bendrojo pobūdžio teisès normos ir pamatiniai teisès principai, bet ir konkretūs standartai, kurių laikantis šie pamatiniai principai gali būti užtikrinti ir igyvendinti. Jau buvo kalbèta apie tai, kad Kodekse nurodoma, kaip iggyvendinti taisykles. Kita vertus, neįmanoma sukurti vieno teisinio norminio akto, kuris sureguliuotų visas teisines situacijas, kurios galetų atsirasti vykdant jūrinę komercinę laivybą. MLC 2006 X straipsnyje pateiktas konvencijų, kurioms MLC 2006 įsigaliojimas daro poveikį, sąrašas. Kita vertus, MLC 2006 kūrèjai, pripažindami šiuolaikinès jūrinès veiklos sudètingumą ir siekdami sukurti maksimaliai palankias sąlygas socialiniam dialogui, MLC 2006 IV straipsnio 5 dalyje valstybei - MLC 2006 dalyvei - nustate pareigą remiantis savo jurisdikcija užtikrinti, kad būtų igyvendintos visos anksčiau aptartos jūrininkų socialinès ir darbo teisès. Dar daugiau, yra nustatyta, kad ,jei šioje Konvencijoje nenurodyta kitaip, toki igyvendinima galima pasiekti per nacionalinius įstatymus ir kitus teisés aktus, taip pat per galiojančias kolektyvines sutartis ar kitas priemones arba praktiškai"(MLC 2006 IV str. 5 d.).

Viename moksliniame straipsnyje neįmanoma ištirti, kiek būtent teisès norminių aktų Lietuvoje reikètų keisti ar papildomai priimti užtikrinant jūrininkų darbo ir socialinių teisių iggyvendinimą, tačiau keletą pastabų būtina išsakyti. Manytina, kad

64 Visuotinè žmogaus teisių deklaracija. Valstybès žinios. 2006, Nr. 68-2497.

65 Europos socialinè chartija (pataisyta). Valstybės žinios. 2001, Nr. 49-1704.

66 Tiažkijus, V., supra note 40, p. 77-81. 
šiuo metu galiojantys Lietuvos teisès norminiai aktai neprieštarauja MLC 2006 nuostatoms ir atitinkamai MLC 2006 savo teisès normomis tik papildo ir tobulina egzistuojančią sistemą. Vis dèlto yra būtina pasisakyti dèl jūrininkų socialinès apsaugos aspektų.

MLC 20064.5 taisyklès 1 dalis ịpareigoja Lietuvą užtikrinti, kad visi jūrininkai ir tiek, kiek nustatyta narių nacionaliniuose įstatymuose, jų išlaikytiniai turètų galimybę naudotis socialine apsauga pagal MLC 2006. Minètos taisyklès 3 dalis konkretizuoja, kad jūrininkai, kuriems yra taikomi jos socialinès apsaugos teisès aktai, ir tiek, kiek nustatyta jos nacionaliniuose ịstatymuose, jų išlaikytiniai turètų teisę i socialinę apsaugą, kuri būtų ne mažiau palanki nei dirbantiems krante. MLC 2006 A 4.5. standarto 1 dalis nustato, kurias sritis reikètų apsvarstyti, siekiant taikyti visapusę socialinę apsaugą. Yra ịvardytos tokios sritys, kaip sveikatos priežiūra, ligos pašalpa, nedarbo pašalpa, senatvės išmoka, sužeidimo darbe pašalpa, šeimos pašalpa, motinystės pašalpa, neigalumo pašalpa ir išgyvenusių asmenų pašalpa. Minėtos taisyklès 2 dalis ịpareigoja valstybę narę užtikrinti, kad MLC 2006 ratifikavimo metu būtų užtikrintos ne mažiau kaip trys iš devynių išvardytų sričių. Pasakytina, jog MLC 2006 4.2 taisyklè turi tikslą užtikrinti, kad jūrininkai būtų apsaugoti nuo finansinių padarinių ligos, sužeidimo ar mirties atvejais, susijusiais su jų darbu. Minètas užtikrinimas yra laivų savininkų atsakomybè. MLC 2006 A 4.2 standartas detalizuoja minimalius reikalavimus, taikomus jūrininkų sveikatos apsaugai ir priežiūrai. I šią sampratą ịeina jūrininkų išlaidos dẻl ligos ar sužeidimo laikotarpiu nuo tarnybos pradžios iki dienos, kai jie laikomi tinkamai repatrijuotais, kompensacijos jūrininko mirties arba ilgalaikio neigalumo dèl profesinio sužeidimo, sveikatos priežiūros (įskaitant medicininị gydymą ir būtinų vaistų bei gydomųjų priemonių suteikimą) išlaidos, laidojimo išlaidų apmokejjimas, jei mirtis ištinka laive arba krante įdarbinimo laikotarpiu, ir kt.

Socialinès apsaugos sistema yra pagrịsta socialine partneryste ir egzistuoja dirbančiųjų ir darbdavių piniginių immokų dèka. Reikètų aptarti jūrininkų socialinès apsaugos užtikrinimo padèti Lietuvoje įsigaliojus MLC 2006. Manytina, kad dar iki MLC 2006 įsigaliojimo TDO konvencijos, papročiai, kolektyvinès sutartys, sudarinèjamos tarp laivų savininkų ir darbuotojų profesinių organizacijų (pvz., Tarptautinė transporto darbuotojų organizacija ${ }^{67}$ ) vienokiu ar kitokiu būdu išspręsdavo pagrindinius jūrininkų socialinės apsaugos klausimus. Kita vertus, yra viena sritis, kuri nesuteikia šios kategorijos darbuotojams tinkamos socialinès apsaugos - tai senatvés išmoka. Atkreiptinas dėmesys, kad MLC 2006 nevartojamas terminas „pensija“.

Trumpa Lietuvos Respublikos valstybinio socialinio draudimo itstatymo ${ }^{68}$ 4 straipsnio, 7 straipsnio nuostatų analizè, Lietuvos Respublikos valstybinių sociali-

67 Seafarers [interaktyvus]. International Transport Workers` Federation [žiūrèta 2014-04-27]. $<$ https://www.itfglobal.org/seafarers/index.cfm $>$.

68 Lietuvos Respublikos valstybinio socialinio draudimo istatymas. Valstybès žinios. 2004, Nr. 171-6295. 
nio draudimo pensijų i̇statymo ${ }^{69} 1$ straipsnio, 20 straipsnio, 31 straipsnio analizė verčia daryti analogišką išvadą. Visus Lietuvos jūrininkus pagal galimybę ateityje gauti senatvės pensiją galima skirstyti $\mathfrak{i}$ šias kategorijas: 1) jūrininkai, dirbantys Lietuvoje ịregistruotose įmonèse, valdančiose laivus (nebūtinai su Lietuvos vèliava); 2) jūrininkai, dirbantys analoginèse įmonėse, esančiose bet kurios ES šalies jurisdikcijoje; 3) jūrininkai, dirbantys įmonėse, kuriose yra kolektyvinès sutartys, nustatančios senatvės išmokas, ir 4) jūrininkai, dirbantys visose kitose įmonèse. Taigi, jei imtumėm domèn, kad dauguma Lietuvos jūrininkų dirba laivuose ir ịmonèse, registruotose ne ES valstybėse, ryškẻja sudètinga socialinè problema, reikalaujanti nagrinejjimo ir sprendimo.

Materialinès teisès norma be leidžiančios ją igyvendinti procedūros yra tuščia deklaracija, todèl visiškai pateisinamas MLC 2006 5.1.5 taisyklès „Skundu laive procedūros" atsiradimas. Vykdant MLC 2006 įsigaliojimo paruošiamuosius darbus buvo priimtas Kolegialių institucijų 2013 m. lapkričio 21 d. įsakymas Nr. 3-592/A1641/V-1075 „Dèl Skundų dèl darbo jūrų laivyboje reikalavimų, nustatytų Lietuvos Respublikos tarptautinese sutartyse ir Lietuvos Respublikos teisès aktuose, galimų pažeidimų prièmimo ir nagrinejjimo tvarkos aprašo patvirtinimo "70 (toliau - Aprašas). Šio poịstatyminio norminio akto priemimas yra teigiamas dalykas, iš esmès šis aktas atitinka MLC 2006 reikalavimus, bet dèl šio akto praktinio taikymo galima išsakyti ir kai kurių pastabų.

Manytina, kad Aprašo 17 ir 18 punktų nuostatos, pagal kurias jūrininkų skundai dèl MLC 20064.3 taisyklès „Sveikatos apsauga ir saugumas, nelaimingų atsitikimų prevencija " galimų pažeidimų perduodami nagrinèti ir Klaipèdos visuomeninès sveikatos centrui (Aprašo 17 p.), ir Lietuvos Respublikos socialinès apsaugos ir darbo ministerijai, kuri skundą išnagrinėja pati arba persiunčia ji nagrinèti jai pavaldžioms institucijoms pagal kompetenciją (Aprašo 18 p.), yra diskutuotinos, o kartu ir keistinos. Vis dèto minètoje taisykleje kalbama apie sveikatos apsaugą ir saugumą bei nelaimingų atsitikimų prevenciją būtent laivuose. Akivaizdu, kad jūrininkų skundus dèl MLC 20064.3 taisyklès turi nagrinèti specialistai, tiek turintys atitinkamą išsilavinimą, tiek atlikę praktiką, susijusią su jūrine laivyba. Manytina, kad siekiant kokybės ir ekonomiškumo būtų tikslingiau kurti atitinkamą padalinį Lietuvos saugios laivybos administracijoje, kas netrukdytų reikalui esant bendradarbiauti su Klaipédos visuomeninès sveikatos centro specialistais arba užsakyti atitinkamas ekspertines išvadas kitose institucijose.

69 Lietuvos Respublikos valstybinių socialinio draudimo pensijų i̦statymas. Valstybės žinios. 2005, Nr. 71-2555.

70 Kolegialių institucijų 2013 m. lapkričio 21 d. įsakymas Nr. 3-592/A1-641/V-1075 „Dèl Skundų dèl darbo jūrų laivyboje reikalavimų, nustatytų Lietuvos Respublikos tarptautinèse sutartyse ir Lietuvos Respublikos teisės aktuose, galimų pažeidimų priemimo ir nagrinejimo tvarkos aprašo patvirtinimo“. Valstybès žinios. 2013, Nr. 121-6153. 


\section{Išvados}

Socialinis teisingumas yra pagrindinis faktorius, kuris gali užtikrinti bendrą ir stiprią taiką, o ekonominè pažanga nèra vienintelis socialinę pažangą skatinantis veiksnys, ir kadangi šiuolaikinè tarptautinẻ laivyba yra globalaus pobūdžio bei jūrininkų darbas susijęs ne tik su technologijų poveikiu, bet ir gamtos veiksniais, kurie kelia papildomus pavojus darbuotojams, atsiranda ypatingas jūrininkų socialinès apsaugos poreikis.

Norminių teisès aktų kodifikacija negali užtikrinti idealų visų teisinių santykių reguliavimą, todèl teisès principai išlieka pagrindinè priemonė ne tik reglamentuojant teisinius santykius, juos aiškinant, užpildant reglamentuojančių teisės aktų spragas ir šalinant kolizijas, bet ir vienija teisès norminius aktus ị vieną darnią sistemą, kurios tikslas - teisingumo įtvirtinimas.

Apibendrinus darbe keliamus uždavinius, galima daryti šias išvadas.

Pirmoji išvada - pagrindiniai darbo teisès principai, ịtvirtinti 2006 m. Konvencijoje dèl darbo jūrų laivyboje, iš esmès atitinka jau nustatytus Lietuvos teisinejje norminèje bazèje analoginius teisès principus. Kolizijų tarp jau galiojančių Lietuvos norminių teisès aktų ir minėtos Konvencijos nuostatų neaptikta.

Antroji išvada - atsakingos Lietuvos institucijos igyvendinant 2006 m. Konvencijos dèl darbo jūrų laivyboje nuostatas šalina teisinio reglamentavimo spragas, kadangi Konvencijoje valstybėms narèms yra palikta galimybė pačioms spręsti, kaip igyvendinti atskirus jos reikalavimus. Kita vertus, kai kurie norminiai teisès aktai turètų būti tobulinami. Pvz., Kolegialių institucijų 2013 m. lapkričio 21 d. ịsakymo Nr. 3-592/A1-641/V-1075 „Dèl Skundų dèl darbo jūrų laivyboje reikalavimų, nustatytų Lietuvos Respublikos tarptautinèse sutartyse ir Lietuvos Respublikos teisès aktuose, galimų pažeidimų prièmimo ir nagrinèjimo tvarkos aprašo patvirtinimo “ 17 ir 18 punktų nuostatos, pagal kurias jūrininkų skundus dèl MLC 20064.3 taisyklès „Sveikatos apsauga ir saugumas, nelaimingų atsitikimų prevencija“ galimų pažeidimų perduodamas nagrinèti ir Klaipėdos visuomeninès sveikatos centrui (Aprašo 17 p.), ir Lietuvos Respublikos socialinès apsaugos ir darbo ministerijai, kuri skundą išnagrinėja pati arba persiunčia ji nagrinèti jai pavaldžioms institucijoms pagal kompetenciją (Aprašo 18 p.), yra netobulos, didina procedūrinès jūrininkų skundų nagrinèjimo išlaidas. Kadangi šie skundai bus susiję su technologiniais jūrinès laivybos aspektais, būtų tikslinga jų nagrinejjimą pavesti vienai institucijai, kuri galètų užtikrinti atitinkamų specialistų dalyvavimą skundų nagrinejjimo procese.

Trečioji išvada - 2006 m. Konvencijos dèl darbo jūrų laivyboje A 4.5. standarto 1 dalis nustato sritis, kurias reikètų apsvarstyti siekiant taikyti visapusę socialinę apsaugą. Konstatuotina, kad senatvés išmokos, numatytos minètos Konvencijos A 4.5. standarto 1 dalyje, išmokèjimo problema jūrininkams, kurie dirba ne ES registruotose įmonèse, nèra išspręsta. 


\section{Literatūra}

Alphabetical list of ILO member countries (185 countries) [interaktyvus]. International labour organization [žiūrèta 2014-04-27]. <http://www.ilo.org/ public/english/standards/relm/count ry.htm>.

Bauer, P. J. The Maritime Labour Convention: An Adequate Guarantee of Seafarer Rights, or an Impediment to True Reforms? Chicago Journal of International Law. 2007-2008, 8(2).

Daniels, Chr. B. Admiralty law. Texas Tech Law Review. 2001-2002, 33.

DiGiovanni v. Traylor Bros., Inc. (1st Cir. 1992) 959 F.2d 1119 [interaktyvus]. Leagle, Inc., 2014 [žiūrèta 2014-0427]. <http://www.leagle.com/decision /19922078959F2d1119_11904>.

Estate of Wenzel v. Seaward Marine Services, Inc. (9th Cir. 1983) 709 F.2d 1326 [interaktyvus]. Leagle, Inc., 2014 [žiūrèta 2014-04-27]. <http://www. leagle.com/decision/19832035709F 2d1326_11794>.

Europos žmogaus teisių ir pagrindinių laisvių apsaugos konvencija. Valstybès žinios. 1995, Nr. 40-987.

Evang, K. Health and Welfare of Seafarers: An International problem. International labour review. 1951, LXIII (1).

Europos socialinè chartija (pataisyta). Valstybès žinios. 2001, Nr. 49-1704.

Gesetze im Internet [interaktyvus]. Bundesministerium der Justiy und für Verbraucherschuty [žiūrèta 2014-0427]. <http://www.gesetze-im-internet. de/bundesrecht/seearbg/gesamt.pdf $>$.

Gesetze im Internet [interaktyvus]. Bundesministerium der Justiy und für Verbraucherschuty [žiūrèta 2014-0427]. <http://www.gesetze-im-internet. de/binschprg/BJNR003010895.html>.
Heise v. Fishing Co. of Alaska, Inc. (1996) 79 F.3d 903 [interaktyvus]. Leagle, Inc., 2014 [žiūrèta 2014-04-27]. $<$ http://www.leagle.com/decision/199 698279F3d903_1834>.

ILO Declaration on Fundamental Principles and Rights at Work and its Follow-up [interaktyvus]. International labour organization [žiūrèta 2014-0427]. <http://www.ilo.org/declaration/ thedeclaration/textdeclaration/lang-en/index.htm>.

International Regulations for Preventing Collisions at Sea [interaktyvus]. Lloyd's Register Rulefinder, 2005 [žiūrèta 2014-04-27]. <http://www. mar.ist.utl.pt/mventura/ProjectoNavios-I/IMO-Conventions\%20 (copies)/COLREG-1972.pdf $>$.

In re Endeavor Marine, Inc. (5th Cir. 2000) 234 F.3d 287 [interaktyvus]. Public. Resource. Org, Inc., 2014 [žiūrèta 2014-04-27]. <https://law. resource.org/pub/us/case/reporter/ F3/234/234.F3d.287.99-30197.html>.

Išduotų dokumentų statistika [interaktyvus]. Lietuvos saugios laivybos administracija [žiūrèta 2014-04-27]. $<$ http://www.msa.lt/lt/papildomasmeniu/statistine-informacija_702/ isduotu-dokumentu-jurininkamsstatistika.html>.

Jankauskas, K. Teisès principų samprata ir jų formulavimo teisès aiškinimo aktuose ypatumai. Jurisprudencija. 2004, 51 (43).

1982 m. Jungtinių Tautų jūrų teisès konvencija. Valstybès žinios. 2003, Nr. 107-4786.

Kolegialių institucijų 2013 m. lapkričio 21 d. issakymas Nr. 3-592/A1-641/V- 
1075 „Dèl Skundų dèl darbo jūrų laivyboje reikalavimų, nustatytų Lietuvos Respublikos tarptautinèse sutartyse ir Lietuvos Respublikos teisès aktuose, galimų pažeidimų prièmimo ir nagrinejjimo tvarkos aprašo patvirtinimo“. Valstybès žinios. 2013, Nr. 1216153.

Kompass September/Oktober 2013, p. 4 [interaktyvus]. Knappschaft Bahn See [žiūrèta 2014-04-27]. <http:// www.kbs.de/DE/00_ueber_uns/33_ bottom_nav/05_kompass__archiv/ ausgabe_2013_09_10.html>.

2006 m. Konvencija dèl darbo jūru laivyboje. Valstybès žinios. 2013, Nr. 78-3941.

Leary Waner, D., et. al. International Studies in Human Right, Volume 84: Social Issues, Globalization and International Institution: Labor Right and the EU, ILO, OECD and WTO. Leiden, NLD, 2005.

Li, K. X.; Ng, J. M. International maritime conventions: seafarers' safety and human rights. Journal of Maritime Law \& Commerce. 2002, 33(3).

Lietuvos Respublikos darbo kodeksas. Valstybès žinios. 2002, Nr. 64-2569.

Lietuvos Respublikos darbuotojų saugos ir sveikatos įstatymas. Valstybès žinios. 2003, Nr. 70-3170.

Lietuvos Respublikos Konstitucija. Valstybès žinios. 1992, Nr. 33-1014.

Lietuvos Respublikos nelaimingų atsitikimų darbe ir profesinių ligų socialinio draudimo istatymas. Valstybes žinios. 2003, Nr. 114-5114.

Lietuvos Respublikos prekybinès laivybos įstatymas. Valstybés žinios. 1996, Nr. 101-2300.

Lietuvos Respublikos saugios laivybos įstatymas. Valstybès žinios. 2000, Nr. 75-2264.
Lietuvos Respublikos valstybinio socialinio draudimo istatymas. Valstybes žinios. 2004, Nr. 171-6295.

Lietuvos Respublikos valstybinių socialinio draudimo pensijų ìstatymas. Valstybès žinios. 2005, Nr. 71-2555.

Lietuvos Respublikos Vyriausybès 2003 m. rugsejjo 30 d. nutarimas Nr. 1195 „Dèl darbuotojų, kurių darbo pobūdis yra susijęs su didesne protine, emocine ittampa, darbo laiko sutrumpinimo tvarkos ir darbuotojų, kuriems nustatytas sutrumpintas darbo laikas, darbo apmokejjimo sąlygų patvirtinimo“. Valstybés žinios. 2003, Nr. 93-4205.

Lietuvos Respublikos Vyriausybès 2002 m. sausio 9 d. nutarimas Nr. 13 „Dèl Lietuvos Respublikos darbuotojų saugos ir sveikatos komisijos nuostatu patvirtinimo“. Valstybès žinios. 2002, Nr. 4-97.

Lietuvos Respublikos Vyriausybès 2006 m. gruodžio 6 d. nutarimas Nr. 1212 „Dèl Lietuvos Respublikos jūrininkų registro“. Valstybès žinios. 2006, Nr. 134-5082.

Lindemann, D.; Bemm, W. Seemannsgesetz und Manteltarifvertrag für die deutsche Seeschiffahrt. 6. Auflage. Becker, 2007.

Mačernytė-Panomariovienè, I. Tarptautinių darbo laivuose standartų ittaka Lietuvos jūrininkų darbo santykiams. Jurisprudencija. 2007, 1(91).

Mikelènas, V., et al. Lietuvos Respublikos civilinio kodekso komentaras. Pirmoji knyga. Vilnius: Justitia, 2001.

Nekrošius, I., et al. Lietuvos Respublikos darbo kodekso komentaras. Pirmas tomas. Vilnius: Justitia, 2003.

Pakalniškis, V., et al. Civiline teise. Bendroji dalis. I tomas. Vilnius: Lietuvos teisès universitetas, 2004. 
Puttfarken, H. J. Seehandelsrecht. Heidelberg: Verlag Recht und Wirtschaft $\mathrm{GmbH}, 1997$.

Robertson, D. W.; Sturley, M. F. Recent Developments in Admiralty and Maritime Law at the National Level and in the Fifth and Eleventh Circuits. Tulane Maritime Law Journal. 20122013, 37.

Seafarers [interaktyvus]. International Transport Workers' Federation [žiūrèta 2014-04-27]. <https://www. itfglobal.org/seafarers/index.cfm>.

The Merchant Shipping (Maritime Labour Convention) (Survey and Certification) Regulations 2013 [interaktyvus]. UK legislation [žiūrèta 201401-24]. <http://www.legisla tion.gov.uk/ uksi/2013/1785/pdfs/uksi_ 20131785_ en.pdf $>$.

1978 m. Tarptautinè konvencija dèl jūrininkų rengimo, atestavimo ir budejimo normatyvų. Valstybès žinios. 2005, Nr. 10-325.

1973 m. Tarptautinès konvencijos dèl teršimo iš laivų prevencijos, papildytos $1978 \mathrm{~m}$. protokolu. Valstybés žinios. 2004, Nr. 138-5030.

1974 m. Tarptautinè konvencija dèl žmogaus gyvybės apsaugos jūroje. Valstybés žinios. 2006, Nr. 128-4887.

TDO konvencija Nr. 182 „Dèl nepriimtino vaikų darbo uždraudimo ir neatidèliotinų veiksmų tokiam darbui panaikinti“. Valstybès žinios. 2003, Nr. 49-2161.

TDO konvencija Nr. 105 „Dèl priverstinio darbo panaikinimo“. Valstybès žinios. 1996, Nr. 28-676.

TDO konvencija Nr. 29 „Dèl priverstinio ar privalomojo darbo“. Valstybès žinios. 1996, Nr. 27-648.

TDO konvencija Nr. 79 „Dèl vaikų ir jaunuolių naktinio darbo apribojimo ne- pramoniniuose darbuose“. Valstybès žinios. 1996, Nr. 27-650.

Tiažkijus, V. Darbo teise: teorija ir praktika. I tomas. Vilnius: Justitia, 2005.

TJO konvencijos, kuriose dalyvauja Lietuva [interaktyvus]. Lietuvos saugios laivybos administracija [žiūrèta 201404-27]. <http://www.msa.lt/lt/teisineinformacija/teises-aktai/tarptautiniaisusitarimai-saugios-9qyq/tarptautinesjuru-organizacijos-konvencijos/tarptautines-juru-organizacijos-9ev8/864/ p0.html>.

Ratification and implementation information for the Maritime Labour Convention, 2006 [interaktyvus]. International labour organization [žiūrèta 2014-04-27]. <http://www. ilo.org/global/standards/maritimelabour-convention/database-ratifi cation-implementation/lang--en/in dex.htm $>$.

Ratifications of MLC - Maritime Labour Convention, 2006 [interaktyvus]. International labour organization [žiūrèta 2014-04-27]. <http://www.ilo. org/dyn/normlex/en/f?p=NORMLEX PUB:11300:0::NO::P11300_INSTRU MENT_ID:312331>.

Roberts v. Cardinal Services, Inc. (5th Cir. 2001) 266 F.3d 368 [interaktyvus]. Leagle, Inc., 2014 [žiūrèta 2014-0427]. <http://leagle.com/decision/2001 634266F3d368_1605>.

Seemannsgesetz [interaktyvus]. Gesetze und Verordnungen des deutschen Bundesrechts im Internet [žiūrèta 2014-04-27]. <http://www.buzer.de/ gesetz/470/>.

United Nations treaty collection [interaktyvus]. United Nations, 2014 [žiūrèta 2013-12-27]. <https://treaties. un.org/Pages/ViewDetails.aspx? src=TREATY\&mtdsg_no=XI-E-1\& chapter $=11 \&$ lang $=\mathrm{en}>$. 
United Nations treaty collection [interaktyvus]. United Nations, 2014 [žiūrèta 2013-12-27]. <https:// treaties.un.org/pages/ViewDetails. a s p x ? s r c = T RE A T Y \& m td s g _ no $=X I-D-8 \&$ chapter $=11$ \&lang $=$ en $>$.

United Nations treaty collection [interaktyvus]. United Nations, 2014 [žiū- rèta 2013-12-27]. <https://treaties. un.org/pages/ViewDetails.aspx? src $=$ TREATY \&mtdsg_no $=\mathrm{X}-13 \&$ chapter=10\&lang $=\mathrm{en}>$.

Visuotinès žmogaus teisių deklaracija. Valstybès žinios. 2006, Nr. 68-2497.

Anotacija. Lietuvoje ìsigalioja 2006 m. Konvencija dèl darbo jūru laivyboje. Straipsnyje analizuojami tiek pagrindiniai, tiek darbo teisès principai, įtvirtinti Konvencijoje. Nustatyta, kad tarp šios Konvencijos ir jau galiojančių norminiu teisés aktu koliziju nèra. Kai kuriuos norminius teisès aktus jürininku darbo ir socialiniu teisiu srityje reikètu patobulinti.

Reikšminiai žodžiai: darbo teisè, darbo teisès principai ir standartai, laivas, igula, jūrininkas, socialinè apsauga.

\section{SEAFARERS' LABOUR AND SOCIAL RIGHTS ACCORDING TO MLC 2006}

\section{Oleg Drobitko}

Mykolas Romeris University, Lithuania

Summary. In 2013, the Maritime Labour Convention, 2006 (MLC 2006) was ratified in Lithuania. The convention has had a big influence on the whole sector of sea shipping. In this article, fundamental labour law principles are analysed, which have been consolidated in the MLC 2006. These principles basically correspond to the already determined analogue principles at Lithuanian law system, considering the issue of collision. Even though Lithuanian authorities have already started to eliminate gaps of the legal regulation in order to implement the Maritime Labour Convention 2006, some regulations (which acceptance fall under the competence of the Member States according to MLC 2006), such as an order, adopted on 21st of November 2013, No. 3-592/A1-641/V-1075, regarding onboard complaints procedure, could be improved. Having analysed legal regulations of Lithuania, the author has come to the conclusion that the issue of an old-age benefit, which has been described in the MLC 2006, standard A4.5, part 1, regarding seamen of Lithuania working on ships registered in non-EU countries, is not regulated.

Keywords: labour law, the principles and standards of labour law, ship, crew, seaman, social security. 
Oleg Drobitko, Mykolo Romerio universiteto Teisès fakulteto Civilinės justicijos instituto lektorius, socialinių mokslų (teisès krypties) daktaras. Mokslinių tyrimų kryptys: civilinė teise, transporto teisè, bankroto teisè.

Oleg Drobitko, Mykolas Romeris University, Faculty of Law, Institute of Civil Justice, lector, Doctors of social sciences (law). Research interests: civil law, transport law, bankruptcy law. 